impurity nuclei showed evidence for disturbing effects which occurred while the ion was coming to rest. Several papers reported particularly accurate values of hyperfine fields which were obtained from the nuclear resonance disturbance of nuclear orientation and angular correlation experiments: this technique although still in its infancy seemed promising. Among the more powerful methods for investigating the static properties of nuclei is that of the hyperfine structure of the $\mathrm{X}$-rays which follow the capture of mu-mesons by atoms. This structure is particularly sensitive to the distribution of electric quadrupole moment in the nucleus. The availability of mu-mesons beams combined with the use of high resolution germanium counters has opened up this important field.

For those who attended the conference this volume is an excellent record of what must have been a valuable and delightful meeting set in the sunshine of California: the editors are to be congratulated on the quality of its preparation. For those familiar with the field and wishing to get up to date and for those wanting to acquaint themselves with these important developments, it is a collection containing many useful and stimulating papers: reading them in this form is certainly easier than searching through learned journals. Nevertheless, this book, which is both large and expensive, has neither the coherence and completeness of a monograph nor the permanent worth of a series of definitive papers and it may not appeal to the discriminating purchaser. M. A. GRACE

\section{RADIO COMMUNICATIONS}

\section{lonospheric Radio Communications}

Edited by Kristen Folkestad. (Proceedings of a NATO Institute on Ionospheric Radio Communications in the Arctic, organized by the Canadian Defence Research Telecommunications Establishment and the Norwegian Defence Research Establishment, at Finse, Norway, April 13-19, 1967.) Pp. $x i+468$. (Plenum: New York, 1968.) $\$ 25.00$.

RodTINE radio sounding of the ionosphere started nearly forty years ago and, although over the years there have been some significant advances in the application of ionospheric data to certain radio communication problems (as, for example, in the forecasting of long-term trends in ionospheric conditions), many practical problems still remain unsolved. This is particularly true of radio communication in high latitudes where the ionosphere is frequently subject to a variety of minor and major unpredictable disturbances. The extreme variability of the polar ionosphere was clearly recognized as early as 1932 at the time of the Second International Polar Year, when the occurrence of the so-called "polar radio blackout" was first identified. Considerable progress has recently been made in understanding many of the basic causes of polar ionospheric disturbances, but much less has been done to combat the consequent problems of radio communication in the Arctic and Antarctic. The satisfactory solution of all long distance radiowave propagation problems calls for the cooperation of the ionospheric physicist, the communication engineer and the practical operator, and in April 1967 a joint meeting of experts in these three fields was organized at Oslo under the auspices of the North Atlantic Treaty Organization. Particular attention was directed to radio communication problems in Arctic regions.

The present volume summarizes the proceedings of that meeting and consists of some thirty papers grouped under the following main sections: morphology of the Arctic ionosphere and ionospheric absorption, LF and VLF communication, scatter communication, H.F communication, system techniques, existing communication facilities and user problems in the Arctic. Each section includes a short summary of the discussions which took place at the conference and a final section is devoted to a survey of future developments in this field. It is clear that the conference, itself concerned with radio communication problems, certainly succeeded in focusing attention on a communication problem of another sort, viz., a certain lack of communication between the various interested parties referred to above. Indeed, the concluding chapter of the volume is entitled "Bridging the Gap between Physicist, Engineer and User".

Although much of the material is necessarily of a general review character and many of the scientific results quoted have appeared in papers published elsewhere, nevertheless, for those specifically concerned with the problems of radio communication in polar regions, the volume should prove a valuable and convenient reference book. The volume is well produced and provided with an adequate author and subject index.

W. J. G. BEYNON

\section{OBITUARIES}

\section{Dr D. W. W. Henderson}

David Willis Witson Henderson was born in Glasgow on July 23, 1903, the only child of the late John and Mary Henderson. A boyhood interest in science and agriculture led him to choose agricultural bacteriology as his major subject when he entered the University of Glasgow and he graduated there in 1926. Ho moved to a teaching post at King's College, University of Durham, where he started research on the diseases of sheep, submitting the results as a thesis for his MSc, which he obtained in 1930. In the same year, he married his first wife, Beatrice Mary Davenport, daughter of Sir Westcott Abell.

In 1931 Hexderson obtaincd a two year Carnegie Research Fellowship with which he went to the Lister Institute of Preventive Medicine and followed this with a Beit Memorial Fellowship from 1932 to 1935 . Here Henderson's interest turned to human pathogens, particularly anaerobes, and he began to publish papers both under his sole name and with his colleagues. $\mathrm{He}_{0}$ submitted a thesis, "Studies on the Sporo Bearing Anaerobes with Experiments on Active and Passive Immunity", to the University of London for his $\mathrm{PhD}$, which he received in 1934. He was awarded his DSc in 1940 for his published work.

Soon after the outbreak of the Second World War, Henderson's experience of the toxins of the Clostridia led him to try to deliver a toxic dose to mice by the respiratory route. The experiment was so successful that his director, Sir John Ledingham, arranged for him to spend part of his working time at the Chemical Defence Experimental Station, Porton, where considerable experience in the handling of toxic aerosols already existed. In 1940, when an MRC Unit was moved to Porton to assess the risk of the use of biological agents against man, Henderson joined it, though he remained a member of the staff of the Listor Institute until 1946. After the United States entered the war, Henderson was sent to assist them to establish an experimental unit and thereafter spent a good deal of time in the USA, where he successfully collaborated with a number of American microbiologists and made many lasting friendships. In recognition of his contribution he was awarded the Medal of Freedom, bronze palm.

By the end of hostilities, it was clear that biological attack was feasible, but Henderson considered that the ad hoc approaches used during the war were unlikely to yield any estimate of the magnitude of the threat. A long term programme of basic research was required and Henderson offered to direct it. After some argument over 